Отримано: 22 жовтня 2018 р.

Прорецензовано: 01 листопада 2018 р.

Прийнято до друку: 14 листопада 2018 р.

e-mail: pdziekan@interia.eu

michaladam.lesniewski@wp.pl
Paweł Dziekański, Michał Adam Leśniewski. Organizational culture and climate in shaping the competitiveness of enterprises - selected problems of soft management of an organization. Наукові записки Національного університету «Острозька академія». Серія «Економіка» : науковий журнал. Острог : Вид-во НаУОА, грудень 2018. № 11(39). C. 47-51.

DOI: $10.25264 / 2311-5149-2018-11(39)-47-51$

Pawel Dziekański, PhD

Institute of Law, Economics and Administration, Jan Kochanowski University in Kielce, Poland

Michał Adam Leśniewski, PhD

Institute of Management Jan Kochanowski University in Kielce, Poland

\title{
ORGANIZATIONAL CULTURE AND CLIMATE IN SHAPING THE COMPETITIVENESS OF ENTERPRISES - SELECTED PROBLEMS OF SOFT MANAGEMENT OF AN ORGANIZATION
}

Culture and organizational climate are factors involved in the process of shaping the competitiveness of organizations, including enterprises. The issues raised in this paper are emphasizing interdisciplinary management and outline the problem, which is a part of a soft management area. The aim of the study is to present organizational culture and climate in shaping the competitiveness of enterprises. A research hipothesis was taken: competitiveness of enterprises can be shaped by culture and organizational climate which are inherent elements of soft management. Presented hypothesis was developed based on the interpretations of literature, which uses, among other things: logical reasoning (otherwise: logical thinking) and perception, allowing to combine different aspects into one compact unit and giving the image of the analyzed reality.

Key words: organizational culture, organizational climate, soft competitiveness, soft management.

Д-р Павел Джсканьський,

Інститут Права, Економіки і Управління, Університет ім. Яна Кохановського у Кельие

д-р Міхал Адам Лсшнсвський,

Інститут Менеджменту, Університет ім. Яна Кохановського у Кєльие

\section{ОРГАНІЗАЦІЙНА КУЛЬТУРА І КЛІМАТ У ФОРМУВАННІ КОНКУРЕНТОСПРОМОЖНОСТІ ПІДПРИЕМСТВ - ВИБРАНІ ПРОБЛЕМИ М'ЯКОГО УПРАВЛІННЯ ОРГАНІЗАЦІЕЮ}

Конкурентоспроможність підприємств спричиняється культурним та організаційним кліматом, щуо є невід'ємним елементом м'якого управління. Метою дослідження є представлення організаційної культури та клімату у формуванні конкурентоспроможності підприємств. Культура та організаційний клімат є факторами, які беруть участь у прочесі формування конкурентоспроможності організачій, зокрема підприємств. Питання, порушені в иььому документі, наголошують на міждисииллінарному менеджменті.

Ключові слова: організаційна культура, організаційний клімат, м'яка конкурентоспроможність, м'яке управління.

Д-р Павел Джеканьский,

Институт Права, Економики и Управления, Университет им. Яна Кохановского в Кельце д-р Михал Адам Лешневский,

Институт Менеджмента, Университет им. Яна Кохановского в Кельие

\section{ОРГАНИЗАЦИОННАЯ КУЛЬТУРА И КЛИМАТ В ФОРМИРОВАНИИ КОНКУРЕНТОСПОСОБНОСТИ ПРЕДПРИЯТИЙ - ИЗБРАННЫЕ ПРОБЛЕМЫ МЯГКОГО УПРАВЛЕНИЯ ОРГАНИЗАЦИЕЙ}

Конкурентоспособность предприятий может определяться культурным и организационным климатом, который является неотъемлемым элементом мягкого управления. Цель исследования - представить организационную культуру и климат в формировании конкурентоспособности предприятий. Культура и организационный климат являются факторами, влияющими на процесс формирования конкурентоспособности организаций, в том числе предприятий. Вопросы, поднятые в этом документе, делают акиент на междисциплинарном управлении.

Ключевые слова: организационная культура, организационный климат, мягкая конкурентоспособность, мягкое управление. 


\section{Introduction}

Every organization seeks to create the development, which can be achieved, among others by soft management based on organizational culture and climate, at the same time inscribing into soft competitiveness. The problem of culture and organizational climate is moved in a number of papers forming the picture of the complexity of their subject matter.

The aim of the study is to present organizational culture and climate in shaping the competitiveness of enterprises. A research hipothesis was taken: (hipothesis 1.) competitiveness of enterprises can be shaped by culture and organizational climate which are inherent elements of soft management. Presented hypothesis was developed based on the interpretations of literature, which uses, among other things: logical reasoning (otherwise: logical thinking) and perception, allowing to combine different aspects into one compact unit and giving the image of the analyzed reality. This method uses, inter alia: theoretical experience, practical experience and theoretical and practical experience (combining theory and practice). This method is widely used in the world of science and business practice, forming the basis of the reactive or proactive human activity both in the world of science, as well as in the world of business practice and mutually permeates the world of science and business practice. In logical reasoning this method may be called the queen of methods (Leśniewski, 2017, p. 78).

\section{Organizational culture and organizational climate - the concept, the essence, the importance}

Organizational culture (Budzanowska-Drzewiecka, Marcinkowski, Motyl-Adamczyk, 2016, p. 5-168) is an integral element (factor) associated with the organization, including the company. This culture is created by a personal culture of employees or managers and executive employees (subordinates) working together for the good of the organization. Organizational culture determines many aspects of the development of any organization. Patterns of thinking, perception or behawior of the organization's members perpetuate in the form of organizational culture. You can even say that organizational culture is a management model based on soft thinking, perception and behaviour of the employees. Culture shapes the life and development of every society. It is a way of life, enabling ties, relations between members of society as well as contacts at the place of work of the organization. Thanks to the culture one can understand the general principles and rules that affect the lives of each of us. Culture is the beginning and the end of the organization. The true nature of man is shaped by the family, peers or place of work. In the process of socialization personality is formulated and the traditions and cultural values are absorbed (Price, Crapo,2003, p. 11).

A very important role in shaping the culture was played by a sociological and anthropological science, paying attention to the fact that culture is not a work of nature, but arises as a result of human labor. Culture is a concept that applies not only in the humanities but also in organization and management, where organizational culture is identified with the company's organizational effectiveness of solutions.

Overall (holistic) approach to culture points to three main categories (Czermiński, Czerska, Nogalski, Rutka, Apanowicz, 2002, s. 583):

1) material category, consisting of techniques aimed at direct satisfying of the material needs;

2) social category, which includes the relationships and connections between people;

3) symbolic category, including general values and spiritual needs of man, societies and organizations.

The beginning of the discussion over organizational culture dates back to 1951 through A. Jaguesa. He defined culture as the traditional way of thinking and actions of members of the organization, which must be learned. By examining the culture of the factory in England - A. Jagues noted that it manifests itself in the scheme of performing the same actions and things, which promotes the formation of the custom accepted by the members of a specific group. In the first half of the twentieth century cultural phenomenon was noted by American sociologist E. Mayo. As a result of research he came to the conclusion that the most important factor is to recognize human performance and listen to the employee by a superior, and it is not, as it is commonly regarded, payment for work done. He highlighted the fact that a culture is formed for a plurality of informal groups that demonstrate the mentality of the group having a common habits and the regularity of performing specific actions. A similar view was shared by P. Blau, who, as a result of the observations, stated that culture is a source of business growth.

Many definitions of organizational culture mean that there is no single definition of capturing all the factors forming the organizational culture. Each author presents his own point of view and therefore onecan determine that are many authors there are so many definitions of culture. According to J. Penca, culture is a system of values, attitudes and patterns of behavior that has been shaped by history. The components of this definition, affect the development of the relations of members of the organization with the external environment, affecting the inner life of an organization (Penc, 1997, p. 207). In turn, M. Koster called the process of organizational culture a characteristic of the limited space-time organization, which held organizational activities, as they are perceived by their actors (Kostera, 1996, s. 13). Culture allows communication between members of the organization, af- 
fects their choices, decisions and actions. The importance of cultural organizations has many aspects including: the economic, financial, political aspect or the aspect of employment and dismissal of employees.

Culture is processes which is happening and therefore defines the climate and the ideology of an organization (Mole, 2000, p. 265). Organizational culture is a set of values that helps its members understand the organization, what it stands for, how it works, what it considers important. Organizational culture (Sułkowski, 2012) is strongly linked to organizational climate and therefore it is worth to point out the differences between climate and organizational culture. First, organizational culture is a relatively stable product and the organizational climate can undergo numerous and rapidly successive changes. Secondly, in different groups - the culture is different, and organizational climate may vary in connection with the boundaries that separate groups of people - eg. the boundaries of organizational units, or ways to control by superiors / managers.

Organizational climate is the same as the feelings of employees that apply to their positions and the atmosphere in the workplace.

\section{Determinants of organizational climate}

Organizational climate should encourage the involvement of employees in the activities of the organization. According to B. Kowalski - involvement of employees expresses the extent to which a person personally starts helping organizations doing better than that is defined by the responsibilities for the position (Smyth, 2009, s. 234).

$\mathrm{K}$. Truss highlights the three dimensions of engagement, taking into account the commitment: cognitive, emotional and physical. In turn, S. Cook supplements them with: thinking, feeling and action. The most obvious form of motivation is the effort. Noteworthy is the fact that the unit functioning in the organization does that: by necessity, a sense of obligation, because of the emotional attachment to the organization.

Forms of involvement of participants in organization complement and penetrate one another. The increase in the involvement of the employees affects the climate of organizations (Lipińska-Grobelny, 2010, p. 216).

Organizational climate is the atmosphere in the organization, which has an impact on the participants of the organization. Each member feels the atmosphere in an individual (subjective) way, eg. as a friendship or hostility, warmth or coldness, distrust or openness, support, or lack thereof, innovation or stagnation, passivity or commitment, tenacity or submission (Mikuła, 2000).

Since the climate of the organization is associated with the perception - it is an individual (subjective). It can therefore talk about the complexity of the climate. On the one hand - it affects employees' motivation and effectiveness, on the other - it is the satisfaction of employees, achieved successes and benefits for the common organization of work.

But there is no pattern that would allow to build the organizational climate based on trust and knowledge. Each organization needs to find and work out the best solutions for themselves. Possible solutions included (Evans, 2005, p. 56-57):

1) resignation from imposing so called ready modes of action on their employees,

2) launching the mechanisms that trigger a sense of belonging to the group,

3) building relationships that build trust and a sense of community,

4) encouraging experimentation,

5) provoking the exchange of knowledge,

6) building an atmosphere in which the origin is of little importance,

7) tolerating errors and helping in drawing conclusions.

Both culture and organizational climate determines the management of the organization. Elaboration of appropriate organizational culture should lead to an increase of of innovation of an organization or enterprise. It can be argued that the climate and organizational culture fully form the ability to soft manage the organization.

4. Factors determining the competitiveness of enterprises versus the climate and organizational culture

The problem of competitiveness (Jedynak, Budzanowska-Drzewiecka, 2017, p. 5-130) is not detached from the reality of the organization (company), it is a necessary condition for achieving a competitive advantage on the market. Competitiveness can be developed in various forms, including in the soft form, in other words through organizational culture and climate. Company's competitiveness should be understood as its ability to efficiently achieve its goals in the arena of market competition (Brdulak, Jakubik, 2010, p. 81). Competitiveness can be seen through many prisms including: the ability, effectiveness and efficiency. There is a view of the success on the global market, which is determined by previously won competitive struggle on the local, regional, national market (Porter, 2001, p. 246).

Analysis of the competitiveness of enterprises lead to the isolation of competitiveness relating to specific areas and factors being the result of competitiveness, which are linked to relationships of cause and effect (Grabska, 2004, p. 212):

Наукові записки Національного університету «Острозька академія», серія «Економіка», № 11(39), грудень, 2018 р. 
1) real (resulting) competition of company,

2) the competitiveness of the enterprise determined by customers,

3) competitiveness of resources and skills of the company,

4) competitiveness of the system of functioning of the economy, defined as the level of economic freedom,

5) competitiveness of the factors of production of the country and the region.

Competitiveness can be seen as a system of objects, events, processes and activities, through which the company seeks to achieve its objectives in the arena of market competition. Competitiveness is the need for organizations to achieve competitive advantage (Baran, 2015, p. 5-182).

The competitiveness of enterprises is shaped by many factors interacting in the short and long term, both endogenous and exogenous. The main problem is to identify those factors that have a significant impact on the competitiveness of a business entity. One can speak of the competitiveness as a variety of components which form it.

Traditional concepts of competitiveness of the company focused on real factors and mechanisms of competitiveness, while the new - on the factors and mechanisms of the sphere of regulation. Z. Pierścionek points out that the traditional concepts of competitiveness of the company focus on basic market factors of competitiveness and their direct sources. According to Z. Pierścionka the most important concepts are (Pierścionek, 2011, p. 93):

1) the concept of cost competitiveness, based on the effects of the large scale of production, specialization, standardization and effects of experience.

2) quality leadership and quality control systems.

3) competition based on the enterprise's market power.

4) marketing concept of competitiveness.

5) cost leadership and differentiation.

Determinants of competitiveness are factors over which the company must respond - predict them, recognize and classify as opportunities or threats, weaknesses or strengths. These factors may cause a positive or negative impact on the process of building a competitive advantage. Actions that lead to the desired level of competitiveness become subject to management.

Competitiveness can be shaped in the form of soft competitiveness (Leśniewski, 2015, p. 231-235). This form of competitiveness is based inter alia on the organizational culture, where culture is a component of the organizational climate. In order to develop the competitiveness of the organization based on soft competitiveness, this climate and organizational culture must have quality employees who, through their commitment, contribute to the achievement of the organization's competitive advantage. The quality of staff is a showcase of the organization. Without man there is no organization, including even virtual organizations. Therefore, happy and motivated employee or employee organization with a serene climate and suitable organizational culture will facilitate the development of competitiveness in order to achieve a competitive advantage.

\section{Summary}

Competitiveness is not only an integral part of achieving competitive advantage, but also the vision of the organization (company) in a strategic perspective. Formation of competitiveness is an extremely important process of recognizing the factors contributing ultimately to gain a competitive advantage. One of the forms and directions of development of competitiveness adopted in this study is soft competitiveness considered through the prism of organizational culture and climate*. Organizational climate as the atmosphere in the workplace can contribute to improving or weakening the effectiveness and organizational efficiency. So conceived organizational climate strongly fall within the norms, values, beliefs and behaviors of employees recognized as organizational culture. Therefore climate favorable to employees and organizational culture is made by important factors of competitiveness, including soft competitiveness. To shape the soft competitiveness one should use a soft management instruments. Following that analysis, we can conclude that the organizational climate and culture are complementary elements of both soft competitiveness and as well as soft management. The organization taking care of the quality of the organizational climate and culture contributes to raising the level of competitiveness resulting ultimately in achieving a competitive advantage.

Research hypothesis presented in the form of: competitiveness of enterprises can be shaped by organizational culture and climate which are inherent elements of soft management after analyzing the research takes the form of a confirmed positive thesis, that competitiveness of enterprises can be shaped by organizational culture and climate which are inherent elements of soft management.

This study is another step in the scientific controversy not only between scientists but also between business practices. Achieving convergence of points of view will contribute to closer cooperation between science and business practice.

${ }^{*}$ Soft competitiveness, including organizational culture and climate, is a research problem of soft management. 


\section{Literature:}

1. Baran M. (red.). Poszukiwanie przewagi konkurencyjnej. Wybrane uwarunkowania. Kraków: Uniwersytet Jagielloński, 2015.

2. Budzanowska-Drzewiecka M., Marcinkowski A., \& Motyl-Adamczyk A. Różnice kulturowe w komunikacji biznesowej. Kraków: Wydawnictwo Uniwersytetu Jagiellońskiego, 2016.

3. Brdulak J., Jakubik P. Instytucjonalne i kulturowe uwarunkowania przedsiębiorczości. Z. Kuciński / Przedsiębiorczość a rozwój regionalny w Polsce. Warszawa: Difin, 2010.

4. Czermiński A., Czerska M., Nogalski B., Rutka R., Apanowicz J. Zarządzanie organizacjami. Toruń: Dom Organizatora, 2002.

5. Evans Ch. Zarządzanie wiedzą. Warszawa: PWE, 2005.

6. Grabska A. Zasoby przedsiębiorstwa a trwałość przewagi konkurencyjnej. Strategie konkurencyjności przedsiębiorstw - wybrane zagadnienia / red. J. Szabłowski. Białystok: WSFiZ, 2004.

7. Jedynak P., \& Budzanowska-Drzewiecka M. (eds.) The Organizational Competitiveness: Approaches \& Challenges. Comprehensive Management Issues. Kraków: Jagiellonian University Press, 2017.

8. Kostera M. Postmodernizm w zarządzaniu. Warszawa: PWE, 1996.

9. Kulisa B. Istota oraz uwarunkowanie konkurencyjności. Rozwój i doskonalenie funkcjonowania przedsiębiorstw. / red. L. Kiełtyka Warszawa: Difin, 2010.

10. Leśniewski M. A. Konkurencyjność miękka przedsiębiorstw. Warszawa: Difin, 2015.

11. Leśniewski M. A. Behavioural-humanistic model of soft competitiveness of enterprises. Jagiellonian Journal of Management. 2017. № 3, 2. P. 77-91.

12. Lipińska-Grobelny A. Kształtowanie marki organizacji przez kulturę organizacyjną firmy. Psychologia zarzadzania w organizacji / red. A. Zawadzka. Warszawa: PWN, 2010.

13. Mikuła B. Klimat organizacyjny a kultura organizacyjna - próba systematyzacji pojęć. Tarnów: Zeszyty Małopolskiej Wyższej Szkoły Ekonomicznej w Tarnowie, 2000.

14. Mole J. Wzorce i bariery kulturowe w przedsiębiorstwach. Warszawa: Prószyński i S-ka, 2000.

15. Penc J. Strategie zarządzania. Warszawa: Placet, 1997.

16. Porter M. E. Porter o konkurencyjności. Warszawa: PWE, 2001.

17. Price W. F., Crapo R. H. Psychologia w badaniach międzykulturowych. Czy ludzie wszędzie są tacy sami? Gdańsk: GWP, 2003.

18. Pierścionek Z. Zarządzanie strategiczne w przedsiębiorstwie. Warszawa: PWN, 2011.

19. Smyth J. CEO - dyrektor do spraw zaangażowania. Kraków: Wolters a Kluwer, 2009.

20. Sułkowski Ł. Kulturowe procesy zarządzania. Warszawa: Difin, 2012. 